\title{
The emotions least relevant to politics? Queering autonomous activism
}

\author{
Eleanor Wilkinson \\ School of Geography, University of Leeds, LS2 9JT, United Kingdom
}

\section{A R T I C L E I N F O}

\section{Article history:}

Received 27 September 2008

Received in revised form

15 May 2009

Accepted 16 May 2009

\section{Keywords:}

Activism

Autonomy

Emotions

Queer

Sexuality

\begin{abstract}
A B S T R A C T
Studies of emotion and activism have often attempted to uncover 'the emotions most relevant to politics' (Goodwin et al., 2001). This suggests that only certain feelings are productive for activism, while other emotions have less relevance for activist theory and practice. In this paper I ask if the notion of politically 'relevant' emotions helps perpetuate a distinction between what is considered political and what is not. This paper builds upon a case study in which I interviewed self-identified queer-activists about their experiences of autonomous activism. These interviews reveal how the everyday emotions surrounding the 'personal' politics of sexuality/intimacy are often seen as either less important, a distraction from, or entirely irrelevant to 'real' political issues. Ultimately, I want to challenge attempts to neatly separate our intimate lives from the public sphere of activism. I argue that it can never just be a matter of politics and emotion, but also the politics of emotion (Ahmed, 2004). Therefore we should not just assume that emotions matter for resistance - without first realizing the importance of resisting these hierarchies of emotion.
\end{abstract}

(c) 2009 Elsevier Ltd. All rights reserved.
Dealing with our own alienation and conditioning is a very hard and unromantic task, which has no room for heroes and martyrs... chucking a brick through a pane of glass or building an incendiary device is piss easy in comparison.

(Anonymous and undated, cited in Abramsky 2001, 563)

Emotions are not just individual, embodied responses to external factors; emotions are also political and can be utilised to maintain the status quo (Illouz 1997, 2007). Yet concurrently, emotions can also be a powerful force for positive social change and can be nurtured to challenge the status quo. For if 'emotions are bound up with the securing of social hierarchy' (Ahmed, 2004: 4) then it follows that emotions must surely also be bound up with the destabilizing of social hierarchy. Consequently, there has been an ever-increasing body of work that aims to bring emotions into social movement studies (Aminzade and McAdam, 2002; Flam and King 2005; Goodwin et al., 2001). As Eyerman (2005: 42) states, social movements are often involved in transforming as well as articulating values, and in the process, creating new and alternative structures of feeling'. Indeed, social movements often seek to activate emotions, working to re-evaluate emotions such as anger and shame, transforming them into emotions that people can work with rather than try to eradicate (Gould, 2002; Holmes, 2004).

In their book Passionate Politics Goodwin, Jasper and Polletta try to outline 'the emotions most relevant to politics' (2001: 13). They

E-mail address: e.k.wilkinson@leeds.ac.uk believe that the emotions scholars should be focussing on when discussing social movements are 'the more constructed, cognitive' emotions, not 'automatic responses'. They go on to state that:

It is for this reason that our analysis of the emotions of protest and politics departs from much work in the sociology of emotions, which has tended to concentrate on intimate settings and long-standing affective relationships... (2001: 13)

However, this appears to be a somewhat simplistic strategy; emotions cannot simply be placed into tables and made into clearcut formulas that will help bring about social change. There is danger in positioning some types of emotions as more important than others; specifically, emotions that come out of intimate settings' may be deemed irrelevant (or certainly less relevant) than other emotions. This assumption seems problematic as it stands at odds with the notion that 'the personal is political'. In this paper I therefore want to challenge attempts to neatly separate our intimate lives from the public sphere. Instead, I want to ask what roles do our everyday intimacies and long-standing affective relationships have on our emotions within activist spaces?

The paper begins with an outline of my theoretical and methodological framework. Firstly I shall give a definition of the varying ways I shall be utilising the term 'queer'. I then give a brief overview of autonomous politics before moving on to my methodology section. The analysis that then follows is split into two broad strands: firstly, I want to highlight some of the problems in attempting to achieve 'emotional liberation' from existing power 
hierarchies within activist space (King, 2005) and, secondly, I want to challenge any division between the intimate and the public. In this paper I shall draw on interviews with those involved in the UK social centres movement, as well as my own engagements with autonomous activism and queer thought. ${ }^{1}$ I examine some of the attempts to create new structures of feeling in autonomous activist spaces. I then aim to challenge some of these positive emotional goals (linked to concepts such as consensus) by documenting the experiences of people who identify as queer in these spaces. I will then move on to make some initial comments about bringing issues of sexuality and intimacy back into wider discussions about activism. Ultimately I argue that scholars should do more than simply recognise the emotional and affectual side to activism. It can never just be a matter of emotions and politics, or the emotions of politics, but also the politics of emotion (Ahmed, 2004).

At the outset I want to briefly outline my use of queer throughout this paper. A queer approach is not just a case of simply looking at the emotions of 'queers' (see Cvetkovich, 2003) or looking at distinctively queer emotions. Rather, a queer take on emotions is about attempting to queer our understandings of emotion itself. Here queer becomes something other than an identity category - queer is a verb, something one does rather than $i s{ }^{2}$ to 'queer' something is to attempt to destabilize dominant understandings-seeing nothing is innate or unchangeable. Through this paper I therefore also aim to address the sidelining of queer theory in wider radical thought. I propose that there is a need to integrate queer thought into wider activist scholarship. Often queer is seen as a term that is only relevant for issues related to sexual politics - often it comes as a token add on: 'anti-racist, feminist and queer. I would assert that queer should always be antiracist, always feminist, always anti-capitalist (though this is of course not always the case-see Kuntsman and Miyake, 2008). Queer is not just a term for those who stand against normative sexuality, but questions all norms, positioning itself in opposition to all power hierarchies and oppressions. ${ }^{3}$ So, this implies that ideas about intimacy should be tied in to a large range of wider discussions about things such as communal living, care, autonomy, consumption and climate change: queer politics therefore isn't just about sexuality (see Brown, 2007 for an overview of the contested use of the term queer within geography). ${ }^{4}$

\section{Autonomy: a fiction romance?}

Before moving on to my methodology section I want to firstly give a brief outline of some of the theoretical principles behind autonomous politics. Autonomous politics are often positioned in direct contrast to previous social movements on the Left. There is

\footnotetext{
${ }^{1}$ See Hodkinson and Chatterton, 2006, Lacey, 2005 for further writing about autonomous centres in a UK context; and Katsiaficas, 1997; Montagna, 2006; Mudu, 2004 for wider work on the social centres movement in Europe.

2 Although for many of my interviewees 'queer' was still used as an identity category.

3 Though I am not arguing that sexuality can ever be entirely absent from queer.

4 This form of queer politics takes inspiration from earlier queer movements such as the UK-based Homocult (1992) who aimed to challenge the classed and racial privileges of mainstream lesbian and gay politics. The queerzine 'movement' of the early 1990s developed alongside a broader anti-capitalist activism, and there are many similarities between the two-such as a DIY ethos, horizontal organizing, direct action and the reclaiming of public space (I have placed 'movement' in scare quotes as it was (is) in no way was homogenous). However, it is important to note that many historical accounts seem to believe that this form of queer activism is something that has now passed, whereas from my personal experience I contend that it is still very much ongoing. Therefore despite the fact that queer politics are constantly evolving there are still attempts to fix it to a specific point in time and history (see Hemmings, 2005 for a similar account of who has the power to write the 'official' stories of feminism's past and future).
}

a conscious move to try and challenge what is perceived to be the failings of previous ways of doing politics-mainly the reproduction of internal power hierarchies, and the inability to deal with difference within these groups. Autonomous social centres therefore attempt to create an open and accessible, horizontally-organized form of activism that (in theory) anyone can be involved in. There has been a conscious effort to abandon any specifically activist label as it is recognized that this may be a site of exclusion (Anonymous, 2000; Chatterton, 2006; Heckert, 2002). The limits of identity politics have been recognized and there is an attempt to move towards a politics of affinity (Day, 2005; McDonald, 2002). ${ }^{5}$ Autonomous centres are based upon a principle of unity in diversity: a place where anarchist, anti-racist, feminist, and queer politics can come together. It is the mixing of different types of activists (and activism) in autonomous spaces that I want to acknowledge in this paper. Sometimes in research on emotions and social movements the spaces of activism can appear somewhat one-dimensional: interviewees are often presented as part of a social movement. Activist space becomes a singular entity marked by commonality; people are part of this group and this group alone. This often overlooks the complex types of activism people are involved in, and the multiple spaces they inhabit (see Chesters, 2003; Chesters and Welsh, 2005 for a critique of traditional social movement theory and its inability to grasp the spatial dynamics of the contemporary alter-globalization movement(s)). ${ }^{6}$

Such debates are relevant to the theorisation of, and practices within, autonomous social centres; which form part of what has been termed 'autonomous geographies', defined by Pickerill and Chatterton (2006: 730) as:

those spaces where people desire to constitute noncapitalist, egalitarian and solidaristic forms of political, social, and economic organization through a combination of resistance and creation. $^{7}$

The creation of autonomous space is direct-action as it allows activists to show that people can, and do, live outside of capitalism, that there are alternatives (Buechler, 2000). ${ }^{8}$ Therefore a key concept in autonomous activism is prefigurative politics-prefiguring the society you want to live in (Graeber, 2002; Jordan, 2002). Autonomous politics are not about some sort of final end result but rather about changing everyday practices in order to create a better world; the journey is the revolution (Franks, 2003; May, 1994). The local is therefore already a site of power that has effects on a global scale: in order to achieve the world we want to see, we should go about it in ways that eliminate hierarchy, exclusion, and oppression in our daily lives (see Kallenburg, 2001). As Chesters and Welsh state:

There is a deep commitment to providing spaces of encounter that involve and invoke recognition, trust building and affectivity that have little obvious instrumental value in terms of immediate social change (Chester and Welsh, 2005: 203)

\footnotetext{
${ }^{5}$ Affinity politics recognizes that there may be a wide range of groups and people that we may share affinity with on certain issues, at certain times. Affinity politics therefore allows a greater degree of flexibility and enables activists to find affinity with other groups who may share similar (yet not necessarily identical) beliefs.

${ }^{6}$ Likewise, geographers have been quick to highlight many of these spatial complexities (see Cumbers et al., 2008; Leitner et al., 2008; Routledge, 2003).

7 Social centres are just one of many spaces in which 'autonomous politics' can take place: other examples include temporary squats and housing co-operatives.

${ }^{8}$ Autonomous politics may therefore challenge some of the emotional expectations that are traditionally associated with social movements such as feelings of failure due to lack of measurable progress (see CrimethInc, 2001; Gordon, 2007).
} 
Internal group dynamics are seen to be important for autonomous groups, and there is an attempt to understand how interpersonal relations may mirror existing social patterns of domination. Decisions in these spaces are made through consensus in order to make sure that everyone has a voice and noone feels out of place. Every group member has the right to veto a decision, so they can block anything that they do not agree with (see Trapeze Collective, 2007). There appears to be a conscious attempt to create a space in which people feel welcome, supported, and comfortable with any decision made. Lacey argues that the shared visions and hopes of the alter-globalization movement 'bring activists together in emotional communities'; and that there is 'shared emotional space' (2005: 289). In my research I wanted to question if this is always the case. Rather than presenting a romanticised account of autonomous politics I want to examine some of the inconsistencies between theory and practice.

\section{Methodology}

There has been a small amount of invaluable work on queer thought and activism, and more particularly on the creation of queer-autonomous space (Brown, 2007; Heckert, 2004). Yet of course queers do not just exist solely in 'queer space'. Some queer activists also form a part of wider activist movements, at both grassroots level and large scale mobilizations in the global justice movement (see Brown, 2007). In the UK, autonomous queer groups and autonomous groups often share spaces and venues (e.g., The Common Place ${ }^{9}$ social centre in Leeds and The Cowley Club ${ }^{10}$ in Brighton). This overlapping of autonomous space and queerautonomous space raises some interesting issues and conflicts.

Through my interviews I wanted give voice to queer-identified people's experiences of inhabiting 'non-queer' autonomous space. I am aware that the concept of 'non-queer' space is deeply problematic, and of course I am not claiming that everyone in this space is indeed not queer. ${ }^{11}$ Rather I use this term to imply that these places do not define themselves as primarily uniting under the banner of queer politics. ${ }^{12}$ Indeed, this paper came about as an unintentional side-project to my main area of study - which looks at how certain self-identified queer-activists have attempted to reject monogamy and normative ideals about romantic love. The data presented here comes out of my pilot interviews. My initial intent was to focus solely on the role of love in queer-activism. However, the open-ended and unstructured nature of the interview process meant that my research began to move into some interesting and unintended areas. In my interviews I found that people very rarely tended to name a particular emotion such as love, and instead my participants tended to speak rather generally and broadly about emotions. They discussed the ways they were meant to feel, about positive and negative emotions, yet often without specifically naming what these emotions are.

The interview sample was relatively small, consisting of ten participants from various cities across the UK. People were recruited to the project through personal contacts and snow-balling. My data was also collected through secondary sources, such as political writing from queer-zines. I certainly do not claim that this

\footnotetext{
${ }^{9}$ http://www.thecommonplace.org.uk/

10 http://www.cowleyclub.org.uk/

11 Moreover this distinction between 'queer space' and 'not-queer space' was often used by my interviewees when discussing their experiences. I have put these terms in scare quotes throughout to draw attention to the dangers of using such simplistic divisions.

12 Likewise, the concept of 'queer space' is also contestable, what makes space 'queer'? (see Oswin, 2008 for an overview).
}

study is anyway representative of the queer position within autonomous activist spaces (and of course I would dispute that such an account is possible or edesirable). Yet I hope that this smallscale study may act as an invitation to begin to discuss some of these issues in greater depth.

Finally, some of my data comes through personal reflection and my own experiences of inhabiting autonomous space. Autonomous activism was first introduced to me in an academic context. Initially I had high expectations about getting involved in this form of activism as I felt it had many overlaps with my own existing experiences of queer politics. This paper is partly an outcome of my own personal disappointment about what autonomous activism could be, and what it often ends up being in practice. This paper was also driven by some of my experiences in the classroom, where issues of sexuality and intimacy often appeared to be seen as separate from wider activist goals. It was spurred by my own frustration that my own research on queer-activism and love is apparently a little bit too trivial to count as real political scholarship. Therefore the emotions behind this paper are mainly those of irritation and anger. Perhaps then, this article is written as a reaction against, to put it in the words of one of my interviewees 'the activist boys who are so assured, so confident that they have all the right answers'.

The analysis that follows is twofold. Firstly I am going to look at some of the 'feeling rules' produced in autonomous space and examine how these are experienced by queer-activists. ${ }^{13}$ Secondly, I aim to expand my analytical gaze from the emotions within spaces of activism, and move to the emotional intimate attachments we have in our personal lives, and then begin to explore what impact these sort of emotions could have on activism.

\section{Fucking activists}

Despite the admirable aspirations of autonomous politics the potentials are not always lived up to in reality (see Osterweil, 2007; Sullivan, 2007). Autonomous politics are meant to be about overcoming the past failings of politics on the Left, and about creating a space without hierarchy that can embrace difference. However, autonomous groups are often accused of failing to incorporate issues of gender or sexuality into their discussions, or paying full debt to the feminist origins of this form of politics. As one queeractivist from Brighton writes:

We... call out to the activist community which still clings desperately to its own gender stereotypes and heterosexism. By meeting within the Cowley Club... we align ourselves with its principles of horizontality, participation and radical politics, but also hope to bring queerness into debates and queer colour into a male-dominated social scene where men continue to be men and women and everyone else are, well, frequently invisible.

(Mark, Queer Mutiny Brighton, vol. 1)

Therefore despite attempts to try to recognize these issues of difference, it appears that in reality these principles may be hard to adhere to. As one of the queer-activists I interviewed commented:

Just because some straight anarcho bloke is wearing a pink fluoro dress on a protest, or at a party, doesn't mean he's not still acting like a macho wanker.

As Gordon notes, the anti-hierarchical structure of autonomous activism can often result in 'hidden hierarchies' (2007: 69). I want to put forward the case that some of the feeling rules produced in autonomous space may contribute to these hidden hierarchies. In

\footnotetext{
13 See Hochschild, 1983 for an in-depth discussion about feeling rules.
} 
attempting to create a supportive space are we left with no place for conflict or dispute? As Ahmed states, often what makes a scenario seem 'happy' is often 'in part what it conceals or keeps from view' (2007: 132).

In my interviews almost all my respondents expressed a sense of frustration that queer politics were not really embraced (or often even acknowledged) in 'straight' autonomous spaces. ${ }^{14}$ One interviewee describes their experience of a group discussion on radical sex:

...when discussing queer politics the issue of radical celibacy came up. One person was like 'I don't get-I mean if not having sex was going to free Tibet then I'd stop having sex, but it's not, so I don't see the point'. Pretty much everyone in the group agreed with him.... The dominant line is like, why does it matter who you fuck, or who you're sleeping with... and yeah I get this, and I even kind of support this view... but at the same time, maybe I actually think it does matter y'know?

Consensus decision making is an attempt to make sure everyone in the group has a voice. Yet the practicalities of this mean that those who do not have the confidence to speak up can often get side-lined in the decision-making process, ${ }^{15}$ as Osterweil states:

..does it matter if we have a fabulously astute and sensitive notion of what a good democratic- non-representative-politics would look like if we cannot involve more people in the conversation? (2007: npn)

These unequal positions of power may not just effect an individual's ability to veto, but also can effect what issues are seen as important to discuss in the first place. In the above example, issues surrounding sexuality were raised but then dismissed. However, in most instances my interviewees commented that these sorts of discussions did not take place at all. So although decisions in these spaces were made horizontally via consensus there can still be problems with what issues are raised to begin with - as one respondent states:

Consensus is a great idea but in reality it gets used for day to day tasks, mundane things, like drawing up a new cooking rota, or deciding whose turn it is to clean up after an event... and even these decisions can take fucking ages, so we're hardly going to want to suggest that we all sit round and discuss the rights and wrongs of hetero-monogamy are we? We'd be there for days!

Therefore, are there limits to the sort of decisions we can make through consensus, with some issues still considered private and not important/or appropriate topics for group decision? Could issues such as monogamy/celibacy/reproduction ever be seen as appropriate subject matters to reach consensus on? Is taking action often seen as a more urgent matter than discussing difference?

I have had similar experiences in my own attempts to discuss sexual politics with activist students. In these discussions issues of sexuality were often met with a liberal response; that people can choose what they want to be, and that all types of sexuality are tolerated. However, sexual politics were not really seen as important for wider political struggles, and any links between the two were either overlooked or dismissed. This is echoed by one of my interviewees who discussed his experiences in 'straighter activist

\footnotetext{
14 This is not to claim that autonomous-queer space is free from power and exclusions (see Ludwin and Wilkinson (unpublished) for an overview of hierarchies in queer space). See also Brown, 2007 for a discussion about how the sex-positive stance of queer groups may be a form of exclusion for many.

15 In the next section I shall go on to argue that consensus could also sideline those who do speak out - with their emotions as often seen as inappropriate and/or hostile.
}

circles': 'where tolerance and acceptance were neatly compartmentalised'. In my interviews the liberal rhetoric of tolerance was sometimes seen as a way of shutting down dialogue before it even has the chance to begin. In tolerating different sexualities these groups felt that they were being inclusive, and therefore there was no need to take the discussions of these issues any further. However, as starr argues, the 'framework of cultural diversity' can 'make it difficult to identify and address internalized oppression within radical and revolutionary countercultures' (2006: 378 ). starr goes on to state that 'we may want to analyse to what extent we are driven by "discovering the other" in a responsible way, and to what extent are we driven by indifference and contempt masked as politics' (Ibid.: 385). In a sense, then, it could be argued that respect for cultural diversity is a strategy that could mask/ignore difference(s).

\section{Feeling(s) out of place: the fetish of consensus}

The dominant feelings that were expressed by my interviewees were those of anger and frustration. However, many of my interviewees recognized that these sorts of feelings were not seen to be appropriate in autonomous space. At times it seems that the emotionally supportive environment that has been created to foster participation, has sometimes led to the reverse; some people may not want to block decisions for fear of causing trouble and disrupting group harmony. At times it appears what we are left with is a very simplistic dual emotional framework-consensus = good/ conflict = bad. ${ }^{16}$ Moreover, it seems that many of my interviewees shared this view; the collective harmony of the group is something that many wanted to preserve. There was sometimes a desire not to speak up or to cause 'unnecessary conflict' within the group; as one respondent states:

It's like you don't want to upset people, because you're not supposed to have these emotions-of anger and frustration-it's not the way things are done here. And I do like this bunch of people... so often this makes it even more difficult to say what I feel. It's like you're trying to cause problems, but in reality I do have these feelings, but I don't feel that my sharing of them is welcomed. It's almost against the flow-out of place.

Strong affective ties are often seen as crucial for a group's wellbeing and continuing prosperity: Goodwin et al. argue that activism is most successful if people have an 'affective attachment to the group', and its success is dependent upon 'the pleasures of being with people one likes' (2000: 20). Yet sometimes with positive affective ties comes a fear to speak out of turn or provoke disagreement. So although the bonds within the group were strong positive emotions and a sense of belonging may not always be as beneficial as some researchers would like us to believe.

I too experienced some of these emotional binds whilst writing this article. I was concerned that the paper could be a read as an attack on autonomous activism, on my colleagues, students, and friends, many of whom are people I like and admire and whose political goals I share. I was worried about saying too much, and felt that I could only take my critique so far. Therefore the seemingly unquestionably good emotional values of autonomous activist groups, although commendable, are not always without flaws-often they can prevent dialogue, by almost shaming people into feelings of co-operation, happiness and contentment. As Holmes states, 'consensus imposes a will to agree, despite ideally involving argument' (2004: 220). In these groups there is a kind of fetish of consensus, a celebration of collective decision making and the

\footnotetext{
16 It sometimes seems that conflict is only seen as appropriate if it is directed externally.
} 
successful settling of dispute (Miles, 2008). Yet of course consensus should be about working through conflict rather than avoiding it entirely. It is therefore important to note that what consensus should be in theory, and what it ends up being in practice, are often two very different things. ${ }^{17}$

Ultimately my interviews revealed that it is not just a case of feeling out of place, but feelings out of place. There was a very specific way people were meant to feel and sometimes they felt they should self-manage their emotions to fit with the ethos of the group. As a result many of my interviewees fell 'out of line with the affective community'; they became 'affect aliens' (Ahmed, 2007: 126). Although autonomous social centres may have attempted to create a radically open space it seems that there can be no straightforward guidelines for achieving 'emotional liberation' from existing power hierarchies (King, 2005: 151). Often discussions about emotional liberation appear to present a vertical understanding of power - 'them' (above) and 'us' (below) - with little explicit consideration to the other ways in which power flows. ${ }^{18}$ At times these accounts position activist spaces as sites of absolute freedom and resistance; a position that queer studies has taught us to be highly wary of. Power often works in subtle ways which we may not even be conscious of (Foucault, 1980, 1988). When old powers are challenged and transgressed new hierarchies often emerge to constrain and control (Hetherington, 1997). Activist spaces can therefore contain their own feeling rules which can produce new counter-hierarchies. It can therefore never be a simple case of escaping from society's regimes of emotion (see Smith, 2002) whilst ignoring the emotional power hierarchies that may emerge within activist groups.

\section{A placelessness to call home}

The refusal to fully engage in discussions about the potential importance of sexuality and intimacy for wider activist goals often resulted in a sense of isolation and feeling excluded from these groups. For some interviewees this eventually resulted in an almost complete withdrawal from 'straighter' activist groups and spaces. As one interviewee commented, this means that 'sometimes I don't engage in activism I would like to, if I can't find other queers around me who want to take part too'. However, others chose not to withdraw entirely and instead adopted a strategy where they moved from non-queer to queer autonomous space, and then back again. An interesting recurring theme that came up in my interviews was how certain people had attempted to transgress the need for attachment and the comfort found in belonging to $a$ particular group. Affinity politics, therefore, has the potential to transcend more established collective identity categories, as it recognizes that who we feel affinity with varies from context to context. Affinity-based organizing acknowledges the multiplicity of our identifications - identifying with rather than identifying as. However, one of the potential critiques of affinity politics could therefore be that this sort of organizing requires less emotional investment and therefore potentially less passion about how these groups are organized. Are there a number of silences that affinity politics relies upon; does it downplay issues of hierarchy and privilege? Consequently affinity-based organizing could become apolitical and valueless. However, in a number of my interviews it was revealed that moving between different groups actually gave certain queer-activists the courage to remain in

\footnotetext{
17 I am therefore not implying that we should abandon consensus; I think it is still a vitally important tool (see Starhawk, 1997 and starr, 2006 for some potential suggestions on how to overcome these difficulties).

18 Many thanks to Gavin and Jenny for this observation.
}

'straighter' activist circles. The temporary emotional refuge found in specifically queer spaces sometimes helped queer activists not just to continue to be involved in 'non-queer' activism, but also gave them the strength to challenge some of the heteronormative or sexist assumptions found within these groups. For example, one of my interviewees recounts her experience of a personal clash with another activist:

It was the sort of encounter I'd always had with macho men on the Left... he was really aggressive and wouldn't let me speak, totally shut down what I was going to say. In the past before I got involved with queer politics I don't think I'd have been able to deal with it.... I used to think that perhaps this was what it had to be like, and that I was going to have to get used to it.... this time was different, I felt like I could cope, because I knew that once it was over I could go back to my queer-feminist friends for advice and support... and actually just being able to laugh about it with them after was such a relief.

Perhaps activism can also be successful without people having an 'affective attachment to the group' (Goodwin et al., 2001: 20). Therefore maybe the continuing prosperity of activism is also reliant upon a certain degree of conflict, and the displeasures of being with people one dislikes. Affinity politics appears to pose a challenge to some of the emotional expectations that have sometimes been associated with traditional identity politics: the feeling that you have to belong to a group and feel commonality with them, and that this one group should be able to meet your emotional needs. The issue of emotional sustainability becomes far more complex when we begin to look at affinity politics; as emotional sustainability may be achieved through a move outside of certain activist groups. Rather than see this as a sign of weakness this to me is one of the greatest strengths of contemporary autonomous activism.

However, it is important to note that transgressing the attachment to belonging to a particular group inadvertently becomes a new form of home; finding a home in placelessness. As one of my interviewees commented, 'most people seem to want to belong to something, even if it's belonging by not belonging'. Yet is 'belonging by not belonging' potentially more open than traditional forms of identity politics? Is it possible to re-imagine home as something less static and grounded? Or is 'belonging by not belonging' a privileged position to adopt?

\section{Are you revolutionary enough to give up your girlfriends? Happiness and comfort}

My interviews showed that if emotions were discussed in autonomous space they were often limited solely to how people conducted themselves within activist space. Many of my interviewees were therefore frustrated that the emotional attachments we have in our private intimate lives were not seen as worthy for discussion, and not important for wider activist causes. There was often a separation between private intimate life and the public space of activism. In this section, therefore, I want to try and turn my discussion towards some of the emotions that my interviewees felt were left unspoken.

Suggesting activists need to be open to the idea of talking about issues of sexuality and intimacy is not a queer rallying call for all straight-identified activists to embrace their bisexuality, leave their partners, or to create some new sexual hierarchy where queer is best. Yet in failing to engage in these discussions, normative intimacy remains unquestioned and a number of interesting issues remain unaddressed. For example, we could ask what role romantic love and coupledom have in preserving the neoliberal order; or question the ecological and environmental impacts of monogamy 
and the nuclear family. ${ }^{19}$ Moreover, talking about our intimate affective ties allows us to discuss how intimate attachments have an impact on an activist over a life-time (Fox, 2001).

Queer therefore raises a broad range of questions about normative intimacy and is not simply shorthand for LGBT politics. I want to argue that this is perhaps what makes queer politics potentially quite threatening for many people's intimate imaginaries. ${ }^{20}$ This is exemplified when I asked one of my interviewees about how she felt about the acceptance of queer politics in autonomous space:

They might be accepting to lesbian and gays but that's cos it's not that dissimilar from normal-it's still a replica of the coupleform. But queer is different... it's about self-questioning. I often find that even mentioning queer politics makes people sort of defensive-maybe because it's about challenging everything that makes them feel happy and secure...

A similar point was made by another of my interviewees who claimed that in straight activist groups 'gay was as much as most of them could comprehend or handle'. Here, it seems that although these groups are willing to accept lesbian and gay politics, queer politics is often a step too far. I think the idea that queer makes people 'sort of defensive' is an interesting point to draw out. ${ }^{21}$ Queer politics is not just about asking people to tolerate others, but asks us to question our own intimate lives, and reflect on our own senses of comfort and belonging. In my research it therefore appeared that some people were only willing to take their discussions about the regimes of emotion so far.

Likewise, I want to propose that perhaps an academic's own personal happiness and attachments may mean that they often don't take their analysis as far as they could. When looking at studies of emotion I think it is important to position the researcher into the work and examine their own intimate emotional investments. A queer reading is not just about challenging taken-for-granted heteronormative assumptions, it can also be about the role of monogamy, long-term relationships and romantic love. Analysing data through a queer lens would hopefully allow us to see some of the blind spots in existing research. For example, in a presentation on autonomous social centres Chatterton (2007) quotes directly from one of his interviewees 'Geoff' who states that 'because we actually have the globalised situation outside - I need to work and I also need to be with my family'. Chatterton goes on to explain how Geoff 'was one of those Punks from the 1980s who certainly now feels he has less time, more constraints on his life, less freedom to get involved in the political projects he wants to get involved in...' The analysis that follows is limited to the role paid work may have on an activist's life-time, with the above quotation reduced to a discussion about how the lack of unemployment benefits in current society may have led to a decline in political activism. Geoff's mention of his family is not elaborated upon. This is a frequent occurrence, and a similar pattern appears in the following quote from Goodwin et al., 'ongoing participation in "high-risk" movements typically requires the mitigation of participants' fears of violent reprisals against one's self or family, or losing one's job' (2001: 19). This is where their analysis ends, and again the importance of the family is never questioned.

\footnotetext{
19 Of course these issues have been addressed at length elsewhere; by feminist scholars, earlier left wing sections of lesbian and gay politics, and various strands of the anarchist movement(s) (see Blatt, 1989; Goldman, 1910; Red Collective, 1973).

20 Of course often this threat can often be met with humour or dismissing queer politics as irrelevant and trivial (as some of my earlier interview quotations seem to suggest).

21 I do not doubt that people can also become 'comfortably queer'.
}

A queer reading could take the analysis further and also question what role our emotional attachment to our families/relationships (even the self) has for radical politics. We could then begin to ask what impact our emotional intimate attachments may have upon the burn-out of activists in later life. Could the prioritizing of particular sexual bonds over friendship lead to a potential retreat from activism into the intimate sphere (erotic attachments and their relationship to activism has only been briefly touched upon by Goodwin, 1997). It appears that our attachments may close off other possible attachments, potentially moving people away from activism.

\section{Queerying emotional sustainability}

The idea that often people do not question what gives them security, happiness and comfort is for me one of the most interesting issues within studies of emotion today. After all, it is hard to stand against what makes people happy, and even harder to see our own comfort and emotional investments. Yet maybe this is unsurprising, for as Calhoun notes: 'we have huge emotional interests in the everyday status quo' (2001: 53). Perhaps, however, we could begin to scrutinise the things we have emotional investments in and attachments to. This, however, seems a difficult task. When discussing the history of emotions, Reddy (2001: 114, emphasis mine) states that:

The concept of emotions as used in the West is closely associated with the individual's most deeply espoused goals; to feel love for one's spouse or fear of one's opponent presumably, is to be moved by those things one most authentically wants. It is hard to see how a person can be oppressed by his or her most authentic, most deeply held goals.

Yet Reddy goes on to argue we must be open to the idea that a person can indeed be oppressed by their 'most authentic' or 'deeply held goals'. If not, then we have 'no grounds upon which to critique Western emotional common sense' (Reddy, 2001: 114). Likewise, there is a large amount of vitally-important feminist work that highlights how we can be subordinated by our emotional attachments to 'what we thought were the innocent pleasures of everyday life' (Bartky, 1990: 119). Yet what implications does this have for prefigurative politics? If we are attempting to free ourselves from all forms of domination then how can we tackle the hierarchies and exclusions that we may not yet be aware of, not least in the realms of our everyday intimacies? At times, for social movements to continue to move there may be a need to question the things we find comfort in. This is not some masculinist reassertion that we should give ourselves to the cause and abandon attachment and intimacy (far from it). Yet we should also remain open to the idea that pleasure and happiness may constrain us, that the things we think of as unquestionably good may be hindering us from being able to re-imagine new ties and new ways of living.

The relation between our 'deeply held' emotional attachments and activism could potentially lead to some interesting future debates. Eyerman (2005: 42) argues that 'the force of emotion is an essential part of what keeps a (social) movement moving and its lack helps explain its decline'. Yet I feel this is a far too simplistic conception of the relation between emotions and movement. As Ahmed argues 'what moves us, what makes us feel, is also what holds us in place, or gives us a dwelling place' (2004: 11). A key task then is not just to look at how we feel emotions in certain spaces, but also how our emotions actively produce space. Does our 'need' for comfort and belonging reproduce certain spaces as home that will always and inevitably exclude Others? (Or can we begin to reimagine home and make a new home out of placelessness?) It could therefore be argued that certain emotions, rather than being 'an 
essential part of what keeps a movement moving', can in fact make us static.

Yet perhaps my desire for people to question their own comfort and happiness may seem somewhat at odds within an issue on emotional sustainability. When beginning to formulate ideas for this paper the term 'sustainability' was one I felt rather uncertain about. Is emotional sustainability something we should always strive for, or could it have some potentially conservative outcomes? When discussing sexuality and intimacy do claims to happiness and stability actually help preserve the status quo? Ahmed (2007) has explored how happiness can have some deeply conformist results, especially in regards to normative intimacies. Is there a danger that we find happiness in normative intimacy because we are constantly told that this is our only route to 'true' happiness? Could emotional sustainability therefore be linked to having 'normal' aspirations and attachments? At times it appears happiness is used as a way to shut down dialogue. Take, for example, the following debate that took place in a 'zine on non-monogamies. One author frames his defence of marriage in an article titled the 'The Only Thing That Matters' along the following lines:

... when someone makes a choice (or in this case when two people make a choice) that does nobody and nothing else any harm whatsoever, and results in them being happier for it, then they have made the right choice. And there the discussion ends (Merrick, 2007, Sexyouality).

Here happiness is 'all that matters', and as a result happiness becomes something that it is almost impossible to question. Yet could they perhaps be happier? And does personal happiness mean we are sometimes unable to see the harm it does to others?

Therefore how can the concept of emotional sustainability be approached from a queer perspective? How can discussions about emotional sustainability avoid becoming a potentially conservative force that could stifle change? A queer approach to emotions will attempt to embrace the ambivalence of emotions-seeing them as constantly in movement. This does not mean that emotions cannot be nurtured for social change, merely that there should be constant awareness of the multiple ways in which power works. ${ }^{22}$ It is at the very moment people claim to have grasped what emotions are (or what they should be) that caution is needed. It is important, therefore, to avoid making simplistic judgments about which emotions are inevitably good for activism, and which are inevitably bad, as ultimately there should be nothing inevitable about any of our findings.

\section{Conclusions: be the change you don't want to see?}

Autonomous prefigurative forms of activism attempt to create new ways of living in the here and now, and are seen as a conscious attempt to 'be the change we want to see' (Gandhi). However, it appears that challenging the affective ties and relationships in these groups may be a substantial challenge. What happens when we are unable to see certain regimes of domination; could certain positive emotions actually be a source of constraint? It is in these affective bonds, and our 'need' for comfort and stability, that some of the most interesting discussions about the limitations or downfall of activist groups could be had. For those who are seemingly content with heteropatriarchal coupledom, issues of sexual politics may not be at the top of their list of political concerns. But the goals of autonomous politics-everyday self-awareness and personal change-should

\footnotetext{
22 See Probyn, 2005 for a nuanced account of how we need to draw out the complexities and the ambiguities of particular emotions. For example the political ramifications of 'shame' is dependent upon who is the 'shamer' and who is 'the shamed'.
}

encompass the changes we want to see in all aspects of our lives. Yet the question remains, what if we don't want to see change in our intimate life, what if it serves us well, keeps us comfortable, keeps us happy? ${ }^{23}$ How can we be the change that we don't want to see?

It is here I think the field of autonomous activism and queer thought could make an important intervention. Autonomous spaces are an attempt to escape from the rules and regulations of the prevailing neoliberal order, to constantly reinvent the world and to dare to imagine alternatives. Yet as Ost (2004: 235) has noted, often those who write about emotions and activism 'are interested in emotions only in protest politics' and in doing so fail to see how certain feeling rules in activist spaces may actually mirror those found in mainstream society. How could autonomous groups differ in their discussions of emotion? Maybe, then, what is needed is the development of (or at least discussion about) autonomous emotions. Of course, this would not be a set of guidelines to achieve emotional liberation, or a fixed new concept of emotions. Rather, it would be an attempt to constantly challenge and rework dominant understandings of emotions and affective ties, to be constantly aware of who or what we may be excluding: to radically re-imagine what we may be capable of emotionally. This approach to emotions is not just about questioning which emotions are good and which are bad, but realizing that in certain contexts, and in certain spaces, and for many people, these binary dualisms may not be quite so clear-cut. For example, in creating a space where anger and frustration become out of place, who is excluded? As Osterweil (2007) states:

Could it be that this failure has everything to do with the language and theoretical approaches of feminist and other subaltern positions we [autonomous movements] have turned to using, but without having had the experiences that produced those theoretical and practical insights in the first place? Perhaps we've misinterpreted many of these new logics - we've read them devoid of their situational contexts, forgetting what they are a reaction against...

A queer-autonomous approach to emotions and politics is therefore a reflexive one: one that is aware that our ideals about 'appropriate emotions' may uphold existing hierarchies-even in our attempts to create a space without domination. In suggesting a specifically queer approach to emotions my desire is not to be prescriptive, or to fix some new framework for incorporating the study of emotion into activism. My aim is to not shut down other possibilities, but to have an open space to discuss (and contest) these issues. As Sedgwick (1993: xii) writes: 'Queer is a continuing moment, movement, motive-recurrent, eddying, troublant'. Queer politics is about constantly imagining alternatives; in the words of Homocult (1992), queer politics must 'queery everything'.

In this paper I have attempted to rethink the place of emotion in activism, and to suggest ways in which research on emotions and research on activism might be brought into productive contact. Using a queer analytical lens, I have tried to unsettle the hierarchy of emotions that suggests that only certain feelings are productive for activism, while other emotions have less relevance in activist theory and practice. My interviews have suggested that the apparent openness of autonomous activist organizing may actually depend on silencing certain types of feeling, such as anger or frustration (which are seemingly only legitimate when directed outward at the ills of

\footnotetext{
23 Of course, the idea that heteropatriarchal coupledom keeps anyone entirely happy is something that I would want to challenge; and perhaps a more accurate description is that it is something that keeps people mostly happy, but not quite. These mixed ambivalent feelings could have some interesting implications for work on emotions and social change, and are certainly something I would wish to expand upon in future work (thanks to Jamie Heckert for this point).
} 
wider society). They have also highlighted how the supposed inclusiveness of autonomous space has implicit limits, for example, in the way that sexuality is contained or bracketed as a private matter, and seen as less relevant to a broader activist project. The notion of politically relevant emotions therefore helps to perpetuate a false distinction between what is considered political and what is not. Yet as I hope to have argued in this paper, our 'everyday' intimate lives and long-standing affective ties are inextricably bound up in any political project that aspires to create a world without domination or hierarchy. And there the discussion begins.

\section{Acknowledgments}

Thanks to Jenny, Gavin and Jamie for their insightful (and extensive!) feedback; to Elspeth Probyn and David Bell for their helpful comments and advice; and to Paul Chatterton for being the exception.

\section{References}

Abramsky, K., 2001. Restructuring and Resistance: Diverse Voices of Struggle in Western Europe. AK Press, Edinburgh.

Ahmed, S., 2004. The Cultural Politics of Emotion. Edinburgh University Press, Edinburgh.

Ahmed, S., 2007. Multiculturalism and the Promise of Happiness. New Formations $63,121-137$

Aminzade, R., McAdam, D., 2002. Emotions and contentious politics. Mobilization 7 (2), 107-109.

Anonymous, 2000. Give up activism. Do or Die: Voices from the Ecological Resistance 9, 160-166

Bartky, S.L., 1990. Femininity and Domination: Studies in the Phenomenology of Oppression. Routledge, London.

Blatt, M.H., 1989. Free Love \& Anarchism: the Biography of Ezra Heywood. University of Illinois Press.

Brown, G., 2007. Mutinous eruptions: autonomous spaces of radical queer activism. Environment \& Planning A 39 (11), 2685-2698.

Buechler, S., 2000. Social Movements in Advanced Capitalism. Oxford University Press, Oxford.

Calhoun, C., 2001. Putting Emotions in their Place. In: Goodwin, J., Jasper, J.M., Polletta, F. (Eds.), Passionate Politics: Emotions and Social Movements. University of Chicago Press, Chicago, pp. 45-57.

Chatterton, P., 2006. 'Give up activism' and change the world in unknown ways. Or, learning to walk with others on uncommon ground. Antipode 38 (2), 259-282.

Chatterton, P., 2007. Autonomous Spaces and Social Centres. Developing and Deepening Anti-Capitalist Urban Strategies? Word University Network: Horizons in Human Geography virtual seminar Series Online at: http://www.wun. ac.uk/horizons/humgeog.

Chesters, G., 2003. Shapeshifting: civil society, complexity and social movements. Anarchist Studies 11 (1) 42-65.

Chesters, G., Welsh, I., 2005. Complexity and social movement: process and emergence in planetary action systems. Theory, Culture and Society 22 (5), 187-211.

CrimethInc, 2001. Days of War, Nights of Love. Crimethinc, Olympia, WA. Online at: http://www.crimethinc.com/texts/days/.

Cumbers, A., Routledge, P., Nativel, C., 2008. The entangled geographies of global justice networks. Progress in Human Geography 32, 183-201.

Cvetkovich, A., 2003. An Archive of Feelings: Trauma, Sexuality and Lesbian Public Cultures. Duke University Press, Durham, NC.

Day, R., 2005. Gramsci is Dead: Anarchist Currents in the Newest Social Movements Pluto Press, London.

Eyerman, R., 2005. How social movements move. In: Flam, H., King, D. (Eds.), Emotions \& Social Movements. Routledge, Oxford, pp. 41-56.

Flam, H., King., D. (Eds.), 2005. Emotions \& Social Movements. Routledge, Oxford

Foucault, M., 1980. Power/Knowledge: Selected Interviews and Other Writings 1972-1977 New York: Pantheon.

Foucault, M., 1988. Technologies of the self. In: Martin, L.H., Gutman, H., Hutton, P.H. (Eds.), Technologies of the Self. University of Massachusetts Press, Amherst.

Fox, D., 2001. From a married anarchist. Social Anarchism 31.

Franks, B., 2003. The direct action ethic: from 59 upwards. Anarchist Studies 11 (1), $13-41$.

Goldman, Emma, 1910. Marriage and Love. Anarchism and Other Essays. Mother Earth Pub. Association, New York, pp. 233-245.

Goodwin, J., 1997. The libidinal constitution of a high-risk movement: affectual ties and solidarity in the Huk rebellion 1947 to 1954. American Sociological Review $62,53-69$.

Goodwin, J., Jasper, J.M., Polletta, F. (Eds.), 2001. Passionate Politics: Emotions and Social Movements. University of Chicago Press, Chicago.
Gordon, U., 2007. Anarchy Alive! Anti-authoritarian Politics from Practice to Theory. Pluto Press, London.

Gould, D., 2002. Life during wartime: emotions and the development of ACT UP. Mobilization 7, 177-200.

Graeber, D., 2002. The new anarchists. New Left Review 13, 61-73.

Heckert, J., 2002. Maintaining the Borders: Identity \& Politics. Green Pepper. Autumn 2002.

Heckert, J., 2004. Sexuality/identity/politics. In: Purkis, J., Bowen, J. (Eds.), Changing Anarchism: Anarchist Theory and Practice in a Global Age. Manchester University Press, Manchester, pp. 101-116.

Hemmings, C., 2005. Telling Feminist Stories. Feminist Theory 6 (2), 115-139.

Hetherington, K., 1997. The Badlands of Modernity: Heterotopia and Social Ordering. Routledge, London \& New York.

Hochschild, A.R., 1983. The Managed Heart. University of California Press, Berkley. Hodkinson, S., Chatterton, P., 2006. Autonomy in the City? Initial reflections on the social centres movement in the UK. City 10, 305-315.

Holmes, M., 2004. Feeling beyond rules: politicising the sociology of emotion and anger in feminist politics. European Journal of Social Theory 7 (2), 209-227.

Homocult, 1992. Queer with Class: the First Book of Homocult. MS ED (The Talking Lesbian) Promotions, Manchester.

Illouz, E., 1997. Consuming the Romantic Utopia: Love and the Cultural Contradictions of Capitalism. University of California Press, Berkley.

Illouz, E., 2007. Cold Intimacies: the Making of Emotional Capitalism. Polity Press, Cambridge.

Jordan, T., 2002. Activism! Direct Action, Hacktivism and the Future of Society. Reaktion, London.

Kallenburg, F., 2001. Desire is speaking. Utopian rhizomes. In: Poldervaart, S., Jansen, H., Kesler, B. (Eds.), Contemporary Utopian Struggles. Communities between Modernism and Postmodernism. Aksant, Amsterdam, pp. 91-99.

Katsiaficas, G., 1997. The Subversion of Politics: European Autonomous Movements and the Decolonisation of Everyday Life. Humanities Press, New Jersey.

King, D., 2005. Sustaining activism through emotional reflexivity'. In: Flam, H., King, D. (Eds.), Emotions \& Social Movements. Routledge, Oxford, pp. 150-169.

Kuntsman, A., Miyake, E., 2008. Out of Place: Interrogating Silences in Queerness/ Raciality. Raw Nerve Books, York, UK.

Lacey, A., 2005. Networked communities. Social centres and activist spaces in contemporary Britain. Space and Culture 8 (3), 286-301.

Leitner, H., Sheppard, E., Sziarto., K.M., 2008. The spatialities of contentious politics. Transactions of the Institute of British Geographers 33 (2), 157-172.

Ludwin, K., and E. Wilkinson (unpublished manuscript) The Annual Festival of Homosexual Misery: Taking Pride in Gay Shame.

May, T., 1994. The Political Philosophy of Poststructuralist Anarchism. Pennsylvania State University Press, University Park.

McDonald, K., 2002. From solidarity to fluidarity: social movements beyond "collective identity" - the case of globalisation conflicts. Social Movements Studies 1 (2), 109-128.

Merrick. (Ed.), 2007. Sexyouality: Challenging the Culture of Monogamy. Godhaven Ink Publications.

Miles, M., 2008. Urban Utopia: the Built and Social Architectures of Alternative Settlements. Routledge, London \& New York.

Montagna, N., 2006. The de-commodification of urban space and the occupied social centres in Italy. City 10 (3), 295-304.

Mudu, P., 2004. Resisting and challenging neoliberalism: the development of Italian Social Centres. Antipode 36 (5), 917-941.

Ost, D., 2004. Politics as the mobilization of anger. European Journal of Social Theory 7 (2), 229-244.

Osterweil, M., 2007. 'Becoming-Woman?' In theory or in practice? Turbulence (1) Online at: http://www.turbulence.org.uk/becoming-woman.html.

Oswin, N., 2008. Critical geographies and the uses of sexuality: deconstructing queer space. Progress in Human Geography 32, 89-103.

Pickerill, J., Chatterton, P., 2006. Notes towards autonomous geographies: creation, resistance and self-management as survival tactics. Progress in Human Geography 30 (6), 730-746.

Probyn, E., 2005. Blush: Faces of Shame. University of Minnesota Press, Minneapolis.

Red Collective, 1973. The Politics of Sexuality in Capitalism. Red Collective and Publications Distribution Cooperative.

Reddy, W., 2001. The Navigation of Feeling: a Framework for the History of Emotions. Cambridge University Press, Cambridge.

Routledge, P., 2003. Convergence space: process geographies of grassroots globalization networks. Transactions of the Institute of British Geographers 28 (3), 333-349.

Sedgwick, E.K., 1993. Tendencies. Duke University Press.

Smith, P., 2002. Regimes of emotion. Soundings 20, 98-217.

starr, a, 2006. Grumpywarriorcool: What makes our movements white? In: Best, S., Nocella, A.J. (Eds.), Igniting a Revolution: Voices in Defense of the Earth. AK Press, Edinburgh.

Starhawk, 1997. Dreaming the Dark: Magic, Sex and Politics. Beacon Press, Boston, MA.

Sullivan, S., 2007. 'Viva Nihilism!' On Militancy and Machismo in (Anti-) Globalization Protest. In: Devetak, Richard, Hughes, Christopher W. (Eds.), The Globalization of Political Violence: Globalization's Shadow. Routledge, London.

The Trapese Collective (Ed.), 2007. Do it Yourself: A Handbook for Changing our World. Pluto Press, London. 